International Journal of Linguistics, Literature and Culture
Available online at https://sloap.org/journals/index.php/ijllc/
Vol. 4, No. 5, September 2018, pages: $1 \sim 13$
ISSN: $2455-8028$
https://sloap.org/journals/index.php/ijllc/article/view/283

\title{
Transformation of Siwa-Sisya Relationship within Hindu Religiosity: Religious Practices in the Globalization Era
}

\author{
A.A. Ngurah Anom Kumbara a \\ Made Wiasti $^{\text {b }}$ \\ A.A. Sagung Kartika Dewi ${ }^{\mathrm{c}}$
}

\section{Article history:}

Received: 10 April 2018

Accepted: 1 September 2018

Published: 4 September 2018

\section{Keywords:}

Market ideology;

Pedanda;

Religiosity;

Siwa-sisya;

Sulinggih;

\begin{abstract}
Through globalization, the ideology of capitalism, with its belief in the free market system and rationalism is spread out throughout the world. This has risen up a crucial phenomenon not only to the transformation of socioeconomic aspects but also to transformations of religiosity. In Bali, Indonesia, there has been a transformation of the Siwa-sisya or patron-client relationship, which is an integral part of the religiosity of Bali Hindus. Traditionally, Siwa resembles to be Pedanda or Pastors from the Brahmana background and sisya is the congregants of the respective Pastors which form a classic patron-client relationship. This research aims at analyzing and explaining the patron-client relationship transformation in Bali and its implications within Hindus practices. By applying a critical ethnography approach, the data was collected through observation, in-depth interview, and literature review. The data was analyzed qualitatively through three interrelated stages, namely data reduction, data presentation, and drawing conclusions or verification. The study reveals that there has been a shift of meaning from Siwa to Sulinggih, in which sisya now a freedom to choose Pastor has based on the market mechanism, which has resulted in a reformulation of the patron-client relationship. Consequently, Sulinggih can be Pastors even though the Pastors come from the non-Brahmana background. Therefore, such a relationship transformation can imply to the personalization of religion, the emergence of internal friction within Hindu communities, and contestation between Pedanda and Sulinggih in attracting sisya or clients on the basis of social capital, economic and symbolic power.
\end{abstract}

2455-8028 ${ }^{\circ}$ Copyright 2018. The Author. This is an open-access article under the CC BY-SA license (https://creativecommons.org/licenses/by-sa/4.0/) All rights reserved.

\footnotetext{
Author correspondence:

A.A. Ngurah Anom Kumbara,

Faculty of Arts, Udayana University, Indonesia

Jalan Pulau Nias No. 13, Denpasar-Bali, Indonesia

Email address: anom_kumbara@unud.ac.id
}

\footnotetext{
${ }^{a}$ Faculty of Arts, Udayana University, Indonesia

${ }^{\mathrm{b}}$ Faculty of Arts, Udayana University, Indonesia

${ }^{c}$ Faculty of Economic and Business, Udayana University, Indonesia
} 


\section{Introduction}

Globalization spread the ideology of capitalism, free market system and materialistic rationalism throughout the worldwide have caused a transformation, not only in the socio-cultural and economic aspects but also in religiosity. The transformation of the capitalist economic system in the context of globalization involves the mode of production, the distribution of goods and services based on the motive of propriety and private ownership in the free market mechanism (Featherstone., at al.,1995; Lewellen, 2002). In this free market mechanism, the process of differentiation and pluralism of values and symbols occurs, exchanged and every consumer has the freedom of choice (Berger, 1973; Giddens, 2005; Bourdieu, 1977). In the religious context, the transformation of aspects of understanding and the interpretation of the people towards his philosophy (tattwa), religious norms and values (ethics) its accompanying (ritual) has shifted as a logical consequence of globalization, in which the exchange of information flows and new ideas in a broad scope takes place intensively.

In line with this, since the Dutch colonial rule of Bali, and then Bali became one of the central tourism destinations of the world, the process of modernization, globalization, and localization are becoming increasingly intensive. This then leads to changes in all aspects of Balinese life, whether social, cultural, economic, environmental and they religiosities. In Bali, Indonesia, there has been a transformation of the Siwa-sisya (patron-client) relationship, which is an integral part of the religiosity of Bali Hindus. Traditionally, Siwa or Pedandas are Pastors from a Brahmana background and sisya are the congregants of the respective Pastors. They form a classic patronclient relationship within religiosity Hindus in Bali. The change of Siwa-sisya relationship, not only related to religious activities, but also in social-politic aspects.

The lawsuit against the hegemonic tradition of Pedanda or griya (household of Brahmana clan) in religious practices of Hindus in Bali did appear around the 1920s together with the strengthening of Hindu religious movement based on soroh in Bali (Triguna, 1990). Polemics about the status of the Pastors emerged as Sulinggih outside Pedanda less gain sympathy and legitimacy from traditional Hindu society, as Sulinggih of Pasek and Pande or Blacksmiths group. The issue of manusapada (human equality) and sarwasadhaka which continually inflamed by these interest groups to gain authority and an equal footing with Pedanda, finally began to get a widespread response of Hindus in Bali, especially the people who live in the city. Some Sulinggih began to be accepted by society, because the Sulinggih is offering a new relationship that is more egalitarian in the context of religiosities, such as holding mass ceremonies at a reasonable cost, simplification offerings, and the more practical process of the ceremony. Therefore the phenomena of Hindu religiosity in Bali is interesting to study. The aim of this research is to analyze and explain the transformation of Siwa-sisya relationships in Bali and the implications within religiosity of Hindu's practices (Arniati, et al.: 2018, Mantra, et al.: 2018).

\section{Research Methods}

This study was designed in the form of qualitative research applying critical ethnography approach. Seeking something more after learning the "meanings" of the meaning to a broader structure of social power and control (Medison, 2012). The data was collected by observation, deep interview with key informants, and document study. The data was analyzed qualitatively through three interrelated stages, namely data reduction, data presentation, and drawing conclusions/verification (Milles and Huberman, 1990). In order to examine the research, the problem is it a concept useful to refer to James Scott concept of patron-client. James Scott explain: “.... a special case of dyadic (two-person) ties, involving a largely instrumental friendship in which an individual of higher socio-economic status (patron) uses his own influence and resources to provide protection or benefits or both, for a person of a lower status (client) who for his part reciprocate by offering general support and assistance, including personal services to the patron" (Scott, 1972a: 92). Relevance also to refer to Anthony Giddens (2010: 70-79), the theory of structuration the structure involves the role of actors, agents, agencies, and structures dynamically. Actors get their position as an actor when able to contribute to the social world. Furthermore, actors transform into agents when the resources they possess are capable of being optimized within the social structure. The transformation of actors into agents is characterized by agency capacity in which legitimacy and power issues are covered. All of these agency transformations take place in the realm of structure, the social institution that enables the operation of all human agency activities. In other words, actor or agent acts not always subject and determined by the structure or habitus, but also influenced by internal motivation in accordance with the context of space and time. Thus, the social 
structure is not established and immune to change, such as the view of structural functionalism, but the structure always constructed by actors and agents through an agency (Suarda, et. al.: 2018).

\section{Results and Analysis}

\section{Shifting Meaning from Siwa or Pedanda to Sulinggih}

The decentralization of religious power has had a major impact on the traditional Hindu religion, in Bali. This can not be separated from the open access of religious knowledge of Hindus in a global era so as to build a religious consciousness that is oriented more on religious text (philosophy-religious), than tradition (sociohistoric-religious). This influence is mainly marked by the re-interpretation of the term "Siwa" in the context of religious rituals. In traditional point of view, Siwa is Pedanda (Pastors) of Brahmana background socially constructed in the religious journey of Hindu people in Bali especially since Dalem Waturenggong government in Gelgel - Klungkung. At that time, there was a fundamental change associated with the structure of the clergy in Bali with the establishment of Danghyang Nirartha into the Pastor stood (Bhagawan/purahita) of the kingdom. Then, Danghyang Astapaka - a Buddhist Pastors (Sogata) - also came to Bali so that they became the most influential religious leaders in the development of Hinduism in Bali. In its development, the descendants of Danghyang Nirartha and Danghyang Astapaka became Pastorshood authorities in a number of kingdoms under Dalem Waturenggong (Anandakusuma, 1986). Observing the facts of history can be understood that the position of Pedanda Siwa-Budha of Brahmana background became so important in the religiousness of Hindus in Bali because it is closely related to the position of a King. This relationship is legitimized textually through the teachings of the Raja-rshi, the unification of the two powers (Kings and Pastors) in the royal system, as mentioned in the Kakawin Ramayana, 1.49, below:

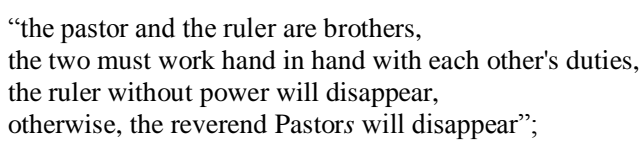

This ideology is practiced throughout the kingdom in Bali, which is marked by the close relationship of the castle with certain griya which by the royal family is recognized as spiritual advisor of the castle (bhagawanta puri). The strength of such a relationship also underlies the importance of the existence of a griya in a royal territory so it becomes the obligation of the castle to place a Pastors (Brahmana clan) in his territory in order to build the socioreligious life of society. The existence of a griya in a royal territory, the griya is the spiritual advisor of the castle in various royal affairs, as well as in the execution of its large ritual (yadnya) centered in the castle. On the contrary, the majority of people (sisya and panjak ) residing in the region become followers (pangiring) in religious ceremonies that are held so as to strengthen the position of the castle and griya as the center of religious orientation of Hindu society. It is in this centralistic religious tradition that the patron-client as social construct begins to wake up, both in the political relations between the puri (Kingdom) and panjak (people) and in the religious relationship between griya and sisya. In great ceremonies such as cremation (pelebon)) or post-cremation (meligya) for the royal family performed by the castle, the relation of the puri-panjak and geriya-sisya looks real. Symbolically, the presence of the King or one of the members of the senior castle and the Pastors (Pedanda) into the public space in the event became the king's representation as an incarnation of the God and Pastors (Pedanda) as the carrier of Siwa (Geertz, 1980).

Brahmana wangsa (clan) as the holder of the clergy authority in the Balinese tradition is commonly called Siwa or Surya. The concept of Siwa, originally referred to the position of the Pastors (Pedanda) as the embodiment of Siwa Gods in the world (Siwa sekala) as in Tattiriya Upanisad I.11 mentioned Acharyadevo bhava ('a minister is the embodiment of the Gods/Siwa). Meanwhile, most people are disciples (sisya) in their meaning as followers of an Acarya (spiritual teacher). Here, the construction of Siwa-sisya is religiously institutionalized in line with the position and function performed by Pastors (Pedanda). But along with the current globalization and the increasing access to public information and religious social movements in Bali, it seems that this Siwa-sisya relationship began to get a rejection from some intellectual circles. A number of formally and non-formal educated Hindu intellectuals began to explore the philosophical-religious understanding of the concept of Siwa in the structure of Hindu learning based on authentic texts. In a modern cultural construct that carries the theme around democracy, participation, and pluralization of values, then the occurrence of meaningful interpretation becomes a cultural necessity in the religiousness of Hindus in Bali. This was prompted by the rise of religious movements based on soroh (clan) around

Kumbara, A. N. A., Wiasti, M., \& Dewi, A. S. K. (2018). Transformation of siwa-sisya relationship within Hindu religiosity. International Journal of Linguistics, Literature and Culture, 4(5), 1-13. https://doi.org/10.21744/ijllc.v4n5.283 
the 1920s. The polemic of discourse occurs mainly between the jaba Wangsa and triwangsa (three custle), but then more specifically between the Brahmana Wangsa with the citizens or clan of Pasek and Pande with regard to the polemic, use titles such as clergy, Pedanda (Brahmana Wangsa), Bhagawan (Kastryawangsa), Rsi bhujangga (Bhujangga wesnawa), Pasek (Pandita mpu), Pande (Sri empu), and Bali Mula or indigenous people (Dukuh) began construction to reinforce the identity of the sinners. All of them, except for Pedanda are generally named Sulinggih.

Pedanda is still supported by the majority of jaba wangsa and triwangsa (three custle clan) as patron-client ties. Instead, Sulinggih trying to seize hegemony through the range of motion, both culturally and structurally. The issue of sarwasadaka (Pastors equality) and manusapada (human equality) that was widely disseminated by the group jaba wangsa or non Brahmana wangsa as a moral struggle for equality and called for equality Pastors. The debate seems to be strengthened with 'Bhisama ancestors' as the transcendental legitimacy of the struggle that inflamed. In fact, religious Hindus in Bali also pointed to the fact that characterized by the presence of a variety of Sulinggih sinners. Those who have raised themselves as Sulinggih begin to struggle to gain a position and recognition that parallels the Pedanda of the Brahmana wangsa. As the legitimacy and rationalization of ideological struggle, a group of Non-brahmana wangsa starts reading and reinterpretation of religious texts in an egalitarian way. One of them said to unravel the knot 'Brahmins' who is not seen as lineage (dynasty), but as a skill or profession (color). Thus, the term 'Siwa' started getting reinterpretation no longer a given status to any person born in the neighborhood of the house, but as gegelaran sesana (role play) that can be taken by anyone who has an initiation into the Pastors. Transformation the meaning of Siwa, from Pedanda or Siwa to Sulinggih in the context of Siwa-sisya relationship becomes a sociocultural necessity because it moves in the same realm, that is Hindu religious ritual. By positioning all Sulinggih as Siwa then sisya have the freedom to determine Pastors which will be utilized its religious services in a religious ceremony. That is, sisya no longer needs to be tied to his Siwa in determining religious choices related to religious ceremonies.

\section{Freedom to choose Pedanda or Sulinggih}

The more understanding of society towards the meaning of Siwa and Sulinggih cause the weaker bond Siwa-sisya relationship in Hindu religious life in Bali. That is, the value of 'substitution ethics' or 'instrumental friendship' that becomes the main node of patron-client relations begins to fade and be replaced by another value. In a modern society marked by the influence of the financial economy, the market has the potential to offer a new value that is more in line with the mechanisms of modern culture in the religiousness of Hindus in Bali. The fundamental change of the entry of the market ideology can be seen in Siwa-sisya's cultural base as a patron-client relationship. In traditional societies, the cultural basis underlying the Siwa-sisya relationship is a generic or hereditary culture (given). Generic culture has a nature that tends to be more closed and difficult to change because it has given so much experience or embodied in the life of Hindus. In the context of the Siwa-sisya relationship in Bali, this tradition has been embodied and institutionalized in Hindu religious life and perpetuated through practical activity. For example, a sisya will consistently use the services of his Siwa (Pedanda) in the conduct of religious ceremonies, will not even move on to another Siwa. In contrast, market ideologies based on differential culture show the soft and fluid relationship of Siwa-sisya, because the bonds are built moving dynamically due to various factors. That is, there is no single factor that causes sisya to establish a relationship with a certain Siwa, but sisya have the freedom to make their own choice (Abdullah, 2006). In modern cultural constructs characterized by structural differentiation, social mobilization, and cultural autonomy. All social relationships can be built on a variety of considerations.

Structural differentiation is characterized by the emergence of new religious power knots outside the Brahmana Wangsa. In addition, also the involvement of individuals (actors) in various social spheres create a community structure that is formed with different values. This condition gives birth to new social ties between actors and actors who have greater power in the relationship. Through the routine practice of praxis, it may be that the social bonds form a new relationship pattern that replaces the previous relations. One example can be seen from the following explanation Astini as information: "in our family, there is Sulinggih that we often use lately to lead the implementation of several ceremonies conducted by the family". Now many people use Sulinggih to complete the ceremony in their family ". The explanation shows that the existence of Sulinggih from the Non-brahmana Wangsa is increasingly functional in the religiousness of Hindus in Bali. In family ties, it becomes a necessity if in the family already exists that Sulinggih then the family who will first utilize his services, then extends to Hindus outside the family. The existence of Sulinggih is finally a new option that can shift Siwa-sisya bond from a tradition that has been inherited before. Moreover, Sulinggih also used the same role play with Pedanda. The influence of a modern culture that is equally important is cultural autonomy, in which each individual (actor) has the freedom to choose his 
religious choice. If Siwa-sisya's relationship is more based on psychic and sociohistorical bonds so that a Sulinggih has greater power to control the relationship, then in the modern world it is the people who have more power. This is in line with the market mechanism in which the variable capital is exchanged transactionally and the consumer has more power in deciding a choice, because of his ability to pay (Lash, 2004).

Looking at the Hindu religious phenomenon in Bali in the context of the Siwa-sisya relationship, it appears that this market mechanism has been so strongly influenced. This is characterized by the more functional Pastors of Nonbrahmana wangsa in the religious of Hindus, especially in religious rituals. Moreover, in the construction of soroh (clan) which position Hindu people on the barriers of kinship (descendants) and the ability of a Sulinggih in utilizing the capital possessed, both symbolic capital, economic, and sociocultural. The description in the previous chapter shows that the Pedanda tends to be conservative because it benefits from the traditional religious structure of sisya as well as established consumers. On the contrary, Sulinggih tends to be more aggressive in constructing their owned capital through religious movements not previously done by Pedanda, in order to win the attention of the people (consumers). In fact, not infrequently rumored issues involved in the construction of discourse to build awareness of Hindus who actually the majority comes from the jaba wangsa (out of Brahmana and Kestrya background).

In this regard, Triguna (2011) noted a number of issues developed by the group jaba wangsa in the context of the clergy, such as "manusapada" (all people are equal), "sarwa shadaka" (Sulinggih of all breeds), "citizens Pande not be affected by holy water (tirta) of Pedanda, and citizens of Pasek as the largest group in Bali. In addition to these issues, as well as important economic discourse in religious Hindus began to get a response from Sulinggih's. Simplifying rituals or rites with a low-cost start with a passage to ease the burden of Hindus in ritual. Not only limited to discourse, but also through practical activities, such as providing packet cremation (Pitra Yajna) equipped with a low cost. Given all this, cremation or Pitra Yajna ritual is seen as a burden for Hindus so cheap package this can be a solution to the problem. The cheap package offered by Santhayana Foundation from Pasek clan is promoted through Baliho with complete package description, as shown can be seen in the following table.

Table 1

Santhayana Foundation Clan of Pasek Sapta Rsi

\begin{tabular}{|c|c|c|}
\hline Type of Ceremony/Offering & Packed Price (IDR) & $\begin{array}{l}\text { Information/ price can be changed } \\
\text { without notice }\end{array}$ \\
\hline $\begin{array}{l}\text { Cremation (Mekinsan Digeni) } \\
\text { (package one) }\end{array}$ & 5.500 .000 & $\begin{array}{l}\text { Ambulances, burning, banten and } \\
\text { sesari }\end{array}$ \\
\hline $\begin{array}{l}\text { Cremation packed two (Ngaben to } \\
\text { nganyut) }\end{array}$ & 11.000 .000 & $\begin{array}{l}\text { Ambulances, burning, banten and } \\
\text { sesari }\end{array}$ \\
\hline $\begin{array}{l}\text { Cremetion packed tree (Ngaben, } \\
\text { nganyut to nyekah/ memukur) }\end{array}$ & 19.000 .000 & $\begin{array}{l}\text { Ambulances, burning, banten and } \\
\text { sesari }\end{array}$ \\
\hline Ngelinggihang offering & 1.000 .000 & For sale \\
\hline Ngerorasin offering & 1.500 .000 & For sale \\
\hline Bebangkit offering with pig & 3.000 .000 & For sale \\
\hline Bebangkit offering with ducks & 2.000 .000 & For sale \\
\hline Suci offering & 20.000 & For sale \\
\hline
\end{tabular}

Source: Santhayana Foundation, 2009. (Legal Entity No. 22/BH/XXVII.0/III/2009) Address: Jl. Cekomaria No. 777 Denpasar, phone (0361) 467 761, Fax. (0361) 467762

The table shows the market for religious rituals that have been constructed in such a way as to provide a solution to the religious ceremonial problems facing Bali Hindus. Given in this organization there are several Sulinggih of Pasek background so that the movement of the organization at the same time can represent the existence Sulinggih it. This certainly provides a new religious experience for Hindus and has the potential to change his religious views over the years. Coupled with the increasing number of Sulinggih's from this clan that appears in the mass media to provide religious enlightenment, the opportunities attracted new customers become more open. In market mechanisms that provide greater power to consumers, transformation or shifting relationships Siwa-sisya relies heavily on the ability of actors and agents to produce commodities through their own resources. The Siwa-sisya relationship will be able to survive when griyas (household of Pedanda) is able to control its traditional ties with sisya through dynamic adaptations that are in line with modern cultural values. In fact, now griya also began to be actively involved in the ritual market, for example selling offering (banten). On the other hand, the existence of Sulinggih in the market

Kumbara, A. N. A., Wiasti, M., \& Dewi, A. S. K. (2018). Transformation of siwa-sisya relationship within Hindu religiosity. International Journal of Linguistics, Literature and Culture, 4(5), 1-13. https://doi.org/10.21744/ijllc.v4n5.283 
mechanism is also determined by its intelligence in building relationships with people through the routine of practical activity which is acceptable to the needs of Hindu people. This difference in resources accumulation (capital) is seen in two somewhat different spheres, are Siwa-sisya bonds generally still survive in the domestic sphere, such as family. On the contrary, in the public sphere, the market mechanism gets the real meaning in which the griya's, both from Brahmana Wangsa and Non-brahmana Wangsa. That is, Siwa-sisya relationship in the public sphere is more fluid, dynamic, and competitive.

\section{Reformulation of Siwa-sisya relationship}

The opening of the knot of Siwa-sisya relationship within Hindu religion in Bali shows the structure of social relations. According to Giddens theory above can be interpreted that the transformation of Sulinggih as agency become a knot shifting relationship Siwa-sisya within the religious of Hindu in Bali. Although Siwa is established in the traditional religious structure of society, this establishment can shift when Siwa (Pedanda) is unable to transform his agency to maintain his social relations with his sisya. This is because the nature of centralized Siwa, social relations began to be decentralized with the emergence of Sulinggih's who have similar agency capacity. In his position as the center of religious power, the position of Siwa is indeed the controller of his social relations with sisya. This is because is the only Hindu's backbone in carrying out religious activities because it is considered the 'most know' and 'most righteous'. This pattern of relations gives legitimacy and power so great to Siwa (Pedanda) that griya becomes dominant, while sisya becomes subordinate. This power is perpetuated by various social facts, such as historical, genealogical, psychic, economic, and religious-mystical bonds. Conversely, power has now spread to a number of actors and the griya is no longer central. Historically, the position and function of the griya have begun to be critically questioned by other clans, for example, that griya as a center for being legitimized by the castle since the days of Dalem Waturenggong. Instead, it appears that the position of Brahmana Wangsa is obtained by shifting the position of the Pastors from other groups, such as Mpu, Dukuh, Kubayan, and so on. That is, resistance to griya becomes necessary when the spirit of the times has changed especially after Bali entered the period of independence and following the republican system. The genealogical bond began to be criticized when the position of the Siwa's just flowed by lineage. Given in social reality, Brahman's descendants are not fully able to maintain the agency capacity they possess as brahmins.

Listening to the weaker bonds that strengthen the position of Siwa (griya) power against the Hindu religion, the reformation of patron-client relations between Siwa and sisya becomes a cultural necessity in the life of a more dynamic and open modern society. In this case, actors and agents have more power in determining the pattern of relationships, including if the pattern of relationships built has shifted from traditional structures. With ethical considerations, Siwa-siya's relationship is no longer dominant - subordinate, because Siwa no longer has the authority to control his social relations. In fact, it is not uncommon for the griya party to be more active in maintaining their relationship with sisya, such as the ethical obligation to visit sisya who are conducting the ceremony. Thus, the shifting form of value in the context of Siwa-sisya is a relationship that is not limited to the religious-cultural dimension, but also the technical and instrumental values. In a technical-instrumental bond, the Siwa-sisya relationship shifts to become more open and dynamic in two directions. For example, the relationship with Siwa is based on technical reasons. Instrumental reason, because without the presence of a Pedanda, the ceremony will not go well. This distinction of a social relation no suggests that such instrumental-technical ties can be taken over by other Sulinggih, so long as the Sulinggih is capable of performing the duties of a Siwa. Conversely, in building relationships with sisya, also Siwa must consider technical factors that more adoption modern values, such as professionalism.

\section{Implications of the transformation of the Siwa-sisya relationship}

\section{a) The occurrence of religious privatization}

Decentralization of religious power causes a shift in meaning towards Siwa to Sulinggih. This shift encourages the emergence of new power centers that deconstruct the traditional social order in its religiosity. The existence of new Pastors (Sulinggih) not born from tradition, but a new intellectual and social movement to gain legitimacy or religious power that breaks the chain of traditionality with a more modern meaning. By becoming a new center of religious power, the knowledge, understanding, and experience of the Sulingih become the new orientation of people in their religiosity. With their knowledge, understanding, and experience, each Sulinggih can disseminate his 
religious ideology to Hindus. The implication is that Hindus are getting richer with references, both derived from religious texts as well as from Sulinggih which are deemed to have the authority to convey religious teachings. This reference richness in addition to adding religious insight, also potentially turning religious awareness earlier in the other direction. In fact, not infrequently because of its different references, Hindus are faced with a confusing situation to determine the choices that best suit themselves and the wider community. This is where dialectics between agents and structures gained significance in building the consciousness of Hindus. The dialectical construction between agents and structures refers to Giddens (Ritzer \& Goodman, 2005; Giddens, 2010), that "agents and structures intertwine inextricably in human practice or activity". Activity is not produced once by social actors, but they are continually reinvented in a way, and in this way they proclaim themselves as actors. In and through their activities, the agency creates the conditions that enable the activity to take place. Thus, social activity is not generated through consciousness, constructiveness of reality, and created by social structure, but by declaring themselves as actors, people engaging in social practice, and through social practice that consciousness and structure are created.

Referring to the opinion it is understood that actors and agents are actively building their social actions, although social structures and realities are an integral part of the birth of the act. In this case, the moment of objectivization and internalization becomes the space for individuals to rationalize and re-invalidate their response to structure and reality (Berger,1973). Giddens (2010) calls this condition a reflexive monitoring measure, namely the rationalization of actions that refer to "deliberate" as a process. That is, social action is done intentionally, either by the agent or the structure in response to the external moments received. It is a common social phenomenon in a modern society that the boundary between private and public space becomes increasingly blurred, even unlimited. The configuration of private space and public space is what gave birth to social practices diverse in social structure. In the context of Hindu religiosity in Bali, the personalization of religion becomes one of the real implications of the increasingly blurred private spaces and public spaces in the life of modern society. If in the public space, 'tradition' gets a more important part, then in the private space logic has greater power. Traditionally it is generally understood that 'good in society is right', otherwise the ratio demands that 'the good must always be based on the right'. Given that individuals have different references to religious teachings, then the redefinition of religion will occur continuously in the private sphere.

Modernization characterized by differences in life have led to the formation of new definitions of things and the birth of diverse life practices. In fact, the ways in which people practice religion undergo change, not because religion undergoes a process of contextualization in society, but because the culture that contextualizes religion is a global culture with different values. In the context of religiosity, this is marked by the transformation of the knowledge system, value system, religious action system because the redefinition of religion takes place simultaneously. Personalization of religion that shows the process of individualization in the appreciation and practice of religion. It is affirmed that the personalization of religion not only shows a widespread public shift but also affects the reorganization of social and cultural systems. As long as freedom is intrinsically linked to 'private rights' - with the modern institutionalization of a private sphere free from interference, both from the government and from clerical control - and because 'privacy' provides the basis for modern liberalism and individualism itself the privatization of religion absolutely essential in modernity (Casanova, 2003). Therefore, Turner (2003) asserts that religious individualism is an emancipatory critique of the growth of rationalism and bureaucratization in modern society.

The emergence of various Hindu religious practices in Bali, in addition to the weakening of the center of religious power, also the emergence of new power centers with their respective system of teaching. This is related to the shifting of Siwa-siya's relationship in which the position of Siwa (griya), except in its traditional aspect, is no longer able to meet the demands of increasingly diverse needs, especially in religious understanding and appreciation. On the contrary, the new centers of religious power are better able to meet the needs of Hindus so as to move them to follow a new pattern that is considered more suitable for itself. Decentralization of religious power is a fact of Hindu religiosity in Bali which is marked by the emergence of new religious power centers outside of Siwa or griya, such as Hindu educational institutions, religious elites, religious institutions, and Pastors from Non-brahmana wangsa. This new center of religious power provides a more diverse and rational reference to Hindus primarily related to the status of the clergy that gave birth to a shift of meaning from Siwa to Sulinggih. This shift in meaning then weakens the association of sisya to their Siwa, because they can gain knowledge and religious appreciation from various sources relevant to their needs. Therefore, the privatization of religion becomes a necessary implication in the relativity of Hindus in Bali today.

\footnotetext{
Kumbara, A. N. A., Wiasti, M., \& Dewi, A. S. K. (2018). Transformation of siwa-sisya relationship within Hindu religiosity. International Journal of Linguistics, Literature and Culture, 4(5), 1-13. https://doi.org/10.21744/ijllc.v4n5.283
} 


\section{b) Widespread inter-Griya's and inter-Pastor's contestation}

The religious personalization resulting from the spread of the center of religious power shows the growing influence of actors and agents in the formation of a system of religious knowledge and action of Hindus in Bali. That is agents who have greater power to create these contradictions with various motivations that lie behind. According to Giddens (2010: 9-10), motivation is the potential action or desire that encourages action. Motivation provides an overall plan or program - projects - underlying a range of behaviors. However, most actors behavior is not based on direct conscious' motivation, but by unconscious motivation. Conscious motivation tends to arise only in deliberate actions with predictable consequences. Conversely, unconscious motivation comes in many actions, whether intentional or not with unpredictable consequences. Therefore, unconscious motivation becomes one of the important elements in structural theory especially in relation to the practical consciousness that often escapes the attention of structuralism. In relation to that unconscious motivation, Giddens (2010: 70-79) affirms Freud's psychoanalytic theory by throwing a number of critics, especially in the context of the agency. According to him, the elements of motivation are not conscious of the act of having their own internal hierarchy, the hierarchy that reveals the 'depth' of the life history of each actor. The life histories of actors - inherent to the creation of agency capacity - are memories that make up the knowledge of human agents. Therefore, discursive consciousness and practical awareness refer to the psychological mechanisms of remembering actions that are practiced in various contexts of action. Strictly speaking, the agency's capacity of actors is not something given but is shaped through the lives of the actors.

In the context of Siwa-sisya's relationship, the birth of Sulinggih's can be attributed to the motivation, both conscious and unconscious motivation. They are generally born from ordinary people (sisya) who have no religious power in the life of Hindus due to the still strong system of Siwa. Therefore, by initiating your/himself into Sulinggih of course there is a hidden motivation from the actor. The commonly cherished cliché is 'to fulfill the spiritual calling', as explained in the chess boarding teaching that the peak of human life is to be a bhiksuka. However, in view of the facts of Hindu religiosity in Bali, one of which is characterized by strong bond-based attributes, it can be interpreted that behind these ideal reasons, it is also possible to explore other motivations from the presence of nonbrahman clan in the context of interrelated became stronger after the 1920s. In the religiosity of Hindus in Bali, soroh (color/clan) has become part of the Hindu religious moral movement which is marked by the establishment of organizations based soroh who emerged since the 1920s. The organization formed since that time, among others: Suita Gama Tirtha (Singaraja, 1921), Sara Poestaka (Ubud, 1923), Surya Kanta (Singaraja, 1923), Perhimpunan Catur Wangsa Dirga Gama Hindu Bali (Klungkung, 1926), Bali Dharma Laksana (Denpasar, 1936), Paruman Para Pandita (Singaraja, 1946), Majelis Hinduism (Klungkung, 1950), Wiwadha Shastra Dharma (Denpasar, 1950), Panti Agama Hindu Bali (Singaraja, 1950), Yayasan Dwijendra (Denpasar, 1953), Perhimpunan Hidup Ketuhanan (Denpasar, 1952), Persatuan Keluarga Bhujangga Waisnawa (Denpasar, 1953), Bali Dharma Yadnya (Sempidi, 1954), and Satya Hindu Dharma (Singaraja, 1956). Some of these organizations contributed to the formation of Parisada Hindu Bali (PHB) as the embryo of the formation of the Parisada Hindu Dharma Indonesia (PHDI) (Triguna, 2011). This confirms that the soroh organization has been involved in various Hindu social and religious movements so that it becomes an integral part of Hindu religious dynamics in Bali

On different aspects, it is well known that these organizations were established for reform in the fields of Hinduism, customs, and education. One of them is Suita Gama Tirtha which expressly states its purpose to make renewal in the field of customs. This movement is closely related to the religiosity condition of Hindu Balinese who still holds strong ajawera tradition, namely the idea that limits a person not to say and disseminate knowledge of religion and philosophy of life, if not timely and accordingly the position (Triguna, 2011). In other words, these organizations can be viewed as an intellectual movement of Balinese Hindus to counter the tradition while building a more egalitarian and democratic.

Such organizations provide greater space and opportunities for the educated to become agents of change and renewal of Hinduism. Subordinate groups whose freedoms have been silenced by tradition are beginning to gain greater opportunities to voice their interests. In contrast, dominant groups that have been comfortable with tradition, provide resistance to subordinate group pressure. The implication is that inter-interest associations differ and in the context of Balinese Hinduism, one of them is marked by an increasingly sharp contrast between the triwangsa and jabawangsa. The conflict between triwangsa and jabawangsa encompasses not only the religious aspect but also the social and political of Balinese Hindu society. From a series of discourses on the ongoing inter-wangsa conflict in Bali, the Pastorshood issue is one of the most important, besides the customary and social injustice issues. The data presented by Triguna (2011) shows that the polemic on the status of the clergy arises because outside Padanda, such as Sulinggih from the citizens Pasek and Pande more actively make the movement to get the same position and 
authority with Padanda. This polemic tapered at the ceremony of Panca Bali Krama (March 8, 1989), Tri Bhuwana (March 21, 1993), and Eka Bhuwana (March 20, 1996) in Besakih Temple. The moment is actually awaited by these citizens to fight for the equality of their ke-Sulinggihan (position) to be able to perform (worship) in the largest temple in Indonesia.

The contestation is reinforced by the strengthening of market mechanisms in Hindu religious rituals, where each Sulinggih has the same opportunity to grab the attention of consumers (Hindus). Moreover, economically, the Sulinggih position can provide promising sources of income when religious rituals have been entirely constructed into market mechanisms. Not only daksina ('giving to the Pastors'), also means the ritual itself has such great economic value. For example, big ceremonies of Hindus in Bali, like Mapadudus Agung and Ngenteg Linggih, its value can reach hundreds of millions to billions of rupiah. The implications of this phenomenon, on the one hand, motivate the Sulinggih to continue to improve their religious knowledge, on the other hand also provides many choices of Hindus in choosing the services of Pastors based on the consideration of the level of knowledge and the price of cheaper service. In the life of Balinese society that is still transitional, from traditional to modern, society still gives a special position to a Sulinggih in various sphere of social life, including politics. The griya's (household of the Pastors) become a knot of strengths that can be optimized for the sympathy of the masses in a political are na, since the position of Sulinggih is also closely related to the power which, directly or indirectly, can give the Sulinggih legitimacy in the wider social structure. This condition is in line with the opinion of Giddens (2010: 448) on strategic behavior, namely the patterns that actors do to explore the structural properties in creating social relations. That is, the nature of the traditional structure of Hindu Balinese society that still provides privileges on the position Sulinggih can be utilized by actors in fostering profitable social relationships.

The implication of all such processes is that the transformation of Siwa-sisya relationships due to the strengthening of market ideology has resulted in the strengthening of inter-griya contestation and contestation between Pastors. In market mechanisms characterized by the inclusion of financial economic strength in the cultural structure, the freedom of society in choosing Pastors can be used as a venue for mass sympathy. In this market mechanism, inter-griya contestation becomes a necessary implication because of the contested resources, either sisya, financial gain, or social-political and power relations. The continued effect of the phenomenon on the religiosity of Hindus in Bali is the occurrence of rationalization of the implementation of religious teachings and the change of values, from the use value to the instrumental value. The strengthening of market ideology is one of the characteristics of modern culture because of the influence of the capitalist economic system. The market has positioned the cultural object (including Sulinggih) into the commodity structure so that it has the same position as other material objects that are sold to the market. Market mechanisms give consumers greater power so that Hindus as consumers - have the freedom to choose Pastor's (Pedanda or Sulinggih) according to their abilities, needs, desires, and even tastes. In the shift of the cultural economy to this financial economy, inter-griya contestation becomes a necessary implication because of the resources contested by the Pastors.

\section{c) The emergence of Hindus internal friction}

The inner political contestation in which the clergy status is covered indicates the formation of a new patronage system in the religiosity of Hindus in Bali. The patronage system in Bali, commonly built through the emotional and instrumental bonds between brahmin families (solar or Siwa) and residents of jabawangsa (panjak or sisya) are routinized in various religious practice. In contrast, patronage systems in the context of modern culture are formed through the bonds of religious service so that Hindus actually have greater freedom to determine the Pastors that will be ordered to attend in religious ceremonies. The implication of this patronage system shift is the defragmentarization of the Pastors region's powers due to the formation of new patronage bonds. Defragmentarization of regionality is characterized by the shift of inherent power centers with subordinate class autonomization in the periphery-subdominant. Regionality is a 'container of power', a place where the dominant class exercises its authority to discipline the subjects in it (Giddens, 2010: 209). In this case, the regionalization occurring in the religiosity of Hindus in Bali, related to the status of the clergy can be divided into two regions, namely the Pastors territory of brahmanawangsa and the Pastors of nonbrahmanawangsa. The regionalism is in line with the operation of power from Pastors that represents the two groups that are contested, namely triwangsa and jabawangsa. Such internal friction is an inescapable implication when the structure of social relations emphasizes the role of actors (agents) in the religious structure of Hindus. That is, the actor whose knowledge and awareness about the clergy has changed will do the rationalization of action in relation to Siwa. Instead, the actors who still maintain their relationship with Siwa will also rationalize their actions to preserve the tradition. In the constellation, internal

Kumbara, A. N. A., Wiasti, M., \& Dewi, A. S. K. (2018). Transformation of siwa-sisya relationship within Hindu religiosity. International Journal of Linguistics, Literature and Culture, 4(5), 1-13.

https://doi.org/10.21744/ijllc.v4n5.283 
friction within the Hindu in the domestic sphere becomes a cultural inevitability when in one family there are two different views about Pastors Sulinggih and Pedanda. This is as stated by Suaryana (interview June 27, 2016): "as far as I know, there are several cases of division within the family caused by different wishes for non-Sulinggih (begging Sulinggih service) during the ceremony in the family. There are those who want to survive with his Pedanda and others want to role Sulinggih which is not Pedanda from his family. Not just different opinions, even I see something to the point (not talking to each other)".

The statement indicates that the reformulation of the Siwa-sisya relationship due to the actor's wishes has not yet been fully accepted by other actors resulting in cross-pollination, even family disunity. Facts that occur in this domestic domain also seems to extend to the public sphere. The process of determining Pastors that will be preserved in ceremonies held at banjar or pakraman village often also gave birth to the polemic in the community due to the different views of the actors in it. This cultural problematically has a greater impact when in one area there are two or more Pastors from different clan groups. Given in the discourse of clerical conflict between the clergy in Bali, that one circle of Pastors not necessarily want to be positioned equivalent to Pastors in another group. For example, Pastors of Brahmana wangsa that still maintain the concept of tri sadhaka, tends only to be juxtaposed with Pastors from Brahmana (Siwa), Buddha, and Rsi Bhujangga so as to close the opportunity for Sulinggih from Pasek and Pande clan to keep together. On the contrary, Pastors from non-brahmana wangsa seems to continue to actively move to get alignment with the Pedanda mainly through the discourse of sarwa sadhaka which continues to be echoed. According to Triguna (2011) that the conflict leads to the seizure of power and authority in controlling the wheels of Hindu spiritual policy in Bali moving from local to national level. Greater noise occurred at Mahasabha (Great Metting) VIII at Hotel Radisson Denpasar (20-24 September 2001) which by some parties was deemed no longer religious nuances. Some Sulinggih especially the guardians of Bali - walk out from the arena of the court and declare no responsibility for all the decisions and stewardship set forth in this Mahasabha VIII. The consolidation of this consolidation continues with the breakup of the Parisada

Hindu Dharma Indonesia (Constitutional Court of Hindu Dharma Indonesia) Bali Province into two, namely the Lokasabha Campuhan (PHDI Campuhan) and Lokasabha Besakih (PHDI Besakih). This split is increasingly tapered by the emergence of a statement of attitudes from the PHDI Campuhan that does not recognize the legitimacy of the Central PHDI stewardship, and vice versa (Sudharta \& Surpha, 2006). The internal friction of Hindus is getting stronger when the non-brahmana clans are more actively engaged in religious movements through their organizations, such as MGPSSR, Maha Bhujangga Waisnawa, Maha Semaya Pande Residents, and so on. The movement of these jabawangsa clan tends to be ideological and emerges in the form of discourse wars. The struggle to place the minister's standing parallel to the Pastor's from Brahmana Wangsa is an important feature of the movements of these two institutions (Triguna, 2011). Similarly, Kumbara (2012), asserted that the problem of the caste system (color), the position and authority of the Pastor to be a dynamic issue in class conflict in Bali. That is the appearance of jaba Wangsa in the public space that brings clergy issues increasingly sharpen the internal friction of Hindus in Bali. Thus the stages of the process of transforming the Siwa-sisya relationship takes place through the stages: the social relations structure, the reformulation of patron-client relations, and the internal friction of Hindus in Bali.

\section{Conclusion}

Based on the above discussion it can be concluded that the transformation of Siwa-sisya relationship within Hindu religion in Bali, namely: a shift of meaning from Siwa to Sulinggih, that all Pastors have the same position, authority and function, freedom of choice to lead religious ceremonies based on market mechanism, and the reformulation of patron-client relationships in various areas of life as a form of Balinese adaptation to modernity. The implications of this transformation are both the personalization of religious practices and conflict interest of Bali Hindu's. In this case the emergence of internal friction of Hindus and contestation between Pastors in fighting for sisya (client) as the basis of economic capital, social and symbolic power. It was found that the transformation of the Siwa-sisya relationship in the context of globalization has an effect not only on the religious dimension but also on the socio-political aspects.

Conflict of interest statement and funding sources

The authors declared that they have no competing interest. The study was financed by Research Institution of the University of Udayana. 
Statement of authorship

The authors have a responsibility for the conception and design of the study. The authors have approved the final article.

\section{Acknowledgments}

We would like to express our gratitude to Udayana University specifically Research Institution of the University of Udayana for the funding of this research. For those who helped us to complete this research on time, we would also like to say thank you.

\section{Footnotes}

Soroh is a term referring to a group of non-Brahmanic ancestry in the color system or caste system of Balinese Hindu's.

Sulinggih is a name for Hindu priests in Bali who have non-brahmana backgrounds such as citizens of clan Pasek and Pande that appear and exist due to modernization.

Sarwasadaka: all pastors have the same position for worship in a large ceremony at Besakih Temple.

Gerya is a household term of the brahmana clan in Bali

Parisada Hindu Bali (PHB) is Constitutional Court of Hindu Bali

Parisada Hindu Dharma Indonesia (PHDI) is Constitutional Court of Hindu Indonesia 


\section{References}

Abdullah, I. (2006). Dekonstruksi Komunitas: Dari Homogenitas Nilai ke Diferensiasi Praktik Sosial. Dalam Konstruksi dan Reproduksi Kebudayaan. Yogyakarta: Pustaka Pelajar.

Arniati, I. A. K. (2018). Young Hindu generation behavior in Denpasar city. International Journal of Linguistics, Literature and Culture, 4(4), 76-85.

Berger, P. L., Berger, B., \& Kellner, H. (1973). The homeless mind: Modernization and consciousness.

Bourdieu, P., \& Nice, R. (1977). Outline of a Theory of Practice(Vol. 16). Cambridge: Cambridge university press.

Casanova, J. (2003). Pendahuluan" dalam Agama publik di Dunia Modern, terj. Nafis Irkham. Surabaya: Pustaka Eureka.

Featherstone, M. (2008). Posmodernisme dan Budaya Konsumen (Consumer Culture and Posmodern). Terjemahan). Yogyakarta: Pustaka Pelajar.

Featherstone, M., Lash, S., \& Robertson, R. (Eds.). (1995). Global modernities (Vol. 36). Sage.

Geertz, C. (1980). Negara. Princeton University Press.

Giddens, A. (2010). Teori strukturasi. Yogyakarta: Pustaka Pelajar.

Giddens, A. (2010). Teori Strukturasi: Dasar-dasar Pembentukan Struktur Sosial Masyarakat. Yogyakarta: Pustaka Pelajar.

Kumbara, S. S., \& Mallaiahb, T. Y. (2008). Changing pattern of user expectations regarding the library catalogue as an information retrieval tool: a case study of Mangalore University.

Lash, S. (2004). Sosiologi Posmodernisme (translated by Gunawan Admiranto/original title: The Sociology of Postmodernism.(London) Yogyakarta:(Rodledge) Kanisius.

Lewellen, T. C. (2002). The Anthropology of Globalization: Cultural Anthropology Enters the 21st Century: Cultural Anthropology Enters the 21st Century. ABC-CLIO.

Mantra, I. B. N., \& Widiastuti, I. A. M. S. (2018). Structural analysis and religiosity of Balinese song lyrics. International Journal of Linguistics, Literature and Culture, 4(4), 69-75.

Medison, S. (1983). Benign prostatic hypertrophy.

Milles and Huberman. (1990). Analisis Data Kualitatif; Jakarta: Universitas Indonesia Press. (pp.77-78).

Ritzer, G., \& Goodman, D. J. (2004). Teori sosiologi modern. Jakarta: Prenada Media, 121.

Scott, J. C. (1972). Patron-client politics and political change in Southeast Asia. American political science review, 66(1), 91-113.

Scott, J. C. (1972). The erosion of patron-client bonds and social change in rural Southeast Asia. The Journal of Asian Studies, 32(1), 5-37.

Suarda, I. W., Yadnyawati, I. A. G., \& Suda, I. K. (2018). Portrait of Hindu religious teacher performance certified educator in junior high schools Denpasar. International Research Journal of Management, IT and Social Sciences (IRJMIS), 5(3), 53-61.

Sudharta, T. R. (2006). Parisada Hindu dharma dengan konsolidasinya. Pāramita.

Triguna, I. B. G. Y. (1990). Munculnya kelas baru dan dewangsanisasi transformasi ekonomi dan perubahan sosial di Bali (Doctoral dissertation, [Yogyakarta]: Universitas Gadjah Mada).

Triguna, I. B. G. Y. (2011). Strategi Hindu. Pustaka Jurnal Keluarga.

Turner, BS. (2003). Agama \&Teori Sosial. Yogyakarta: IRCiSoD, (pp.269). 


\section{Biography of Authors}

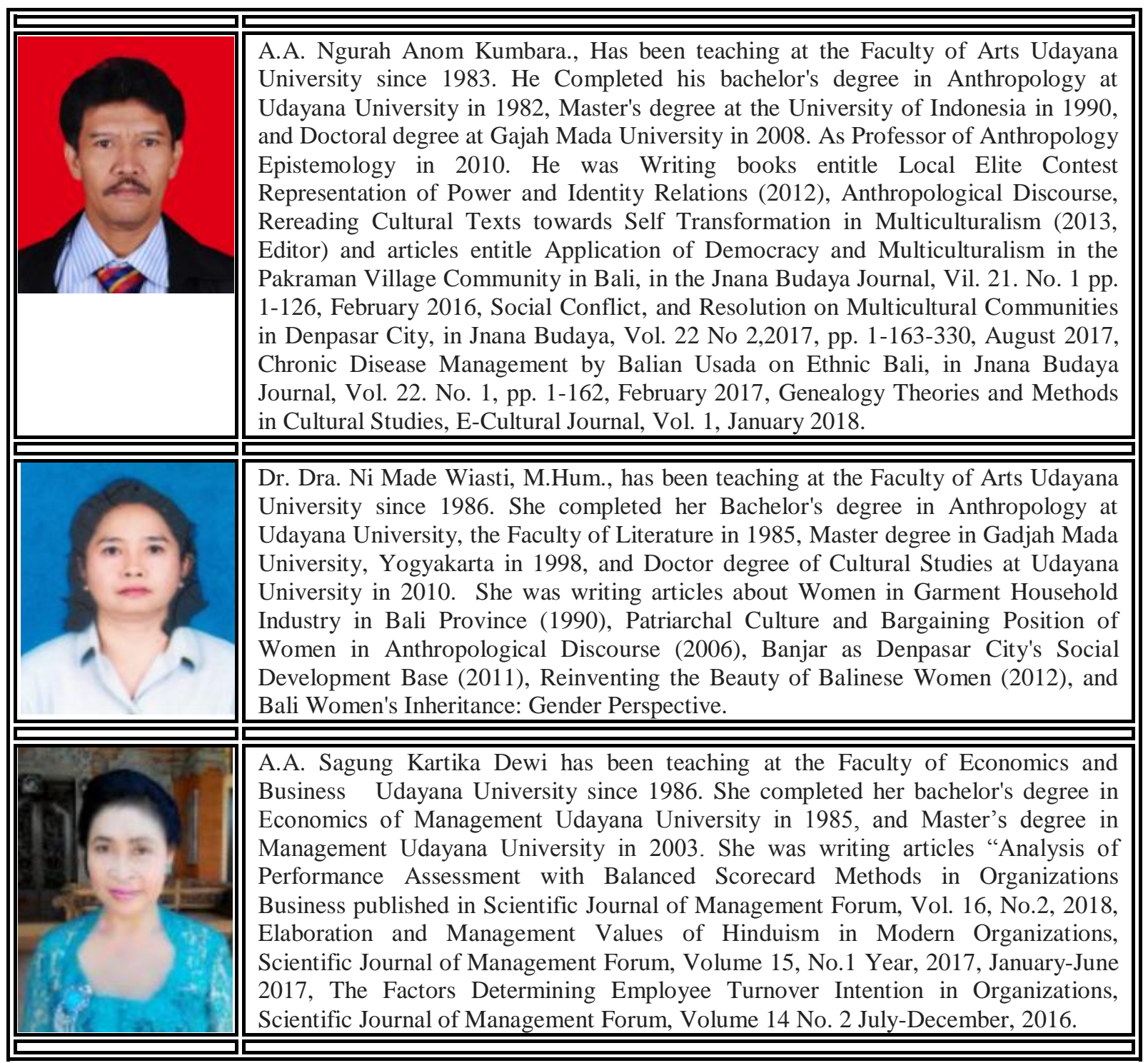

Kumbara, A. N. A., Wiasti, M., \& Dewi, A. S. K. (2018). Transformation of siwa-sisya relationship within Hindu religiosity. International Journal of Linguistics, Literature and Culture, 4(5), 1-13. https://doi.org/10.21744/ijllc.v4n5.283 